\title{
HAS EBOLA INFECTED THE MARKET: A CONTAGIOUS REACTION TO A (MEDIA) HEALTH CARE CRISIS?
}

\author{
Mary Funck \\ Sam Houston State University • Huntsville, TX \\ Jose Gutierrez \\ Sam Houston State University • Huntsville, TX
}

\section{ABSTRACT}

We examine the impact of Ebola headline news days on media-highlighted stocks. An Ebola news day (negative or positive in nature) is associated with increased trading, higher share volume, higher dollar volume, and increased share turnover. OLS regressions on industry-specific portfolios reveal that airline, restaurant, and cruise ship returns reverse themselves one day after the Ebola news event, a result that is consistent with behavioral overreaction literature. Empirical findings could be used to prepare market participants for analogous epidemics.

Keywords: Ebola outbreak; Media attention; Market sentiment; Market efficiency; Return Reversal

JEL Classification: G11; G12; G14; G17

\section{INTRODUCTION}

In 2014, the world became a captive audience to the events surrounding the Ebola crisis. Media headlines continually broadcasted the status of the epidemic, as the disease spread from its African origins to threaten the safety of the world population. The increasing presence of this infectious pathogen, particularly when in September it breached U.S. borders, created fear and panic, and it destroyed, for many U.S. constituents, a sense of well-being.

The Centers for Disease Control and Prevention (CDC) describes Ebola as a potentially fatal disease caused by infection with one of the Ebola virus strains. Ebola was first discovered in 1976 in what is now the Democratic Republic of Congo; sporadic outbreaks of the virus have occurred since then, but have been contained primarily to the African continent. The Ebola virus is spread through direct contact with body fluids of an infected person or contaminated objects. Symptoms, which include fever, pain, weakness, fatigue, diarrhea, vomiting, and hemorrhaging, may appear typically from 8 - 10 days but as few/many as 2 to 21 days after exposure to the virus. 
The 2014 Ebola epidemic affected multiple countries, including the U.S., and resulted in more than twenty-six thousand cases and eleven thousand deaths worldwide. ${ }^{1}$ This incident's impact, however, may extend beyond the obvious physical or emotional consequences. As stated in the Wall Street Journal, "the indirect costs of public risk aversion can generate far more economic damage than the direct cost of healthcare outlays and other containment expenditures." (Casey 2014). The intent of this research is to examine whether or not the series of events surrounding the Ebola crisis and the ensuing media coverage had a significant impact on sectors of the economy aligned closely with the Ebola crisis.

\section{LITERATURE REVIEW}

We derive support for our inquiry into this incident from three specific streams of finance literature: research concerning influence on the financial sector generated by (a) medical crisis; (b) media coverage; and (c) investor sentiment. We hypothesize that the Ebola crisis, along with the resulting media coverage and subsequent change in investor sentiment, each individually impacted market performance on securities that were closely aligned with the crisis.

Several recent studies focus on the impact of a medical crisis on financial markets. Chen et al. (2007) focus on the Severe Acute Respiratory Syndrome (SARS) outbreak and its impact on Taiwanese tourism stocks. The authors report a 29 percent decline in Taiwanese industry stock prices, with hotel stocks demonstrating significantly negative cumulative mean and abnormal returns. McTier et al. (2013) examine the reaction of stock markets to influenza outbreaks. In U.S. markets, a higher incidence of influenza is associated with decreases in trading, volatility, and returns, as well as higher bid-ask spreads. Finally, Wang et al. (2013) study how contagious diseases affect the performance of biotechnology firms. Their results indicate an association between infectious epidemics and significant abnormal returns.

Another group of studies examine media coverage and its impact on stock market performance. Tetlock (2007) finds that high media pessimism predicts downward pressure on market prices followed by a revision to fundamentals. Fang and Peress (2009) study the cross-sectional relation between media coverage and expected stock returns. They find that stocks with no media coverage earn higher returns than stocks with high media coverage even, after controlling for well-known risk factors.

\footnotetext{
${ }^{1}$ Ebola discussion reflects information found on the $\mathrm{CDC}$ and $\mathrm{CNN}$ sites
} 
Lastly, another literature stream focuses on how investor sentiment affects security valuation. Baker and Wurgler (2006) find that when beginning-of-period proxies for sentiment are low, subsequent returns are relatively high for small, young, high-volatility, unprofitable, non-dividend paying, extreme-growth, and distressed stocks. Alternately, when sentiment is high, these categories of stocks earn relatively low subsequent returns. Schmeling (2009) examines whether consumer confidence, as a proxy for individual investor sentiment, affects expected stock returns internationally in 18 industrialized countries. He finds that for the U.S., sentiment negatively forecasts aggregate stock market returns on average across countries. When sentiment is high, future stock returns tend to be lower and vice versa. Finally, Bollen and Mao (2011) argue that investor behavior can be shaped by whether they feel optimistic or pessimistic about future market values. Moreover, they purport that the question is no longer whether social mood and investor sentiment affect stock prices, as it was a few decades ago, but rather how we can best measure and model their effects.

\section{$\overline{\text { MOTIVATION }}$}

The objective of this study is to combine these literature streams and provide a comprehensive analysis of the Ebola crisis. We simultaneously incorporate all of these influences (medical crisis, media coverage, and investor sentiment) to better understand their impact on the market behavior of securities belong to four industries related to the crisis: (a) airlines; (b) restaurants; (c) cruise ships; and (d) pharmaceuticals.

\section{Airline Industry}

Surrounding outbreaks of contagious disease, additional restrictions are often imposed on air transportation. These restrictions may include increased inspection of passengers traveling or cancelling flights to/from an infected region. Beyond these restrictions, passenger traffic might decrease as potential customers cancel their travel plans from fear of disease transmission. Accordingly, the New York Post reports that American Airlines noted a measurable decline in bookings immediately following a U.S. congressional hearing on Ebola.

The negative impact of contagious disease on airlines is exemplified by a previous health crisis, the SARS 2003 outbreak. During this period, the airline industry suffered losses estimated at $\$ 1$ billion. The industry overall lost 12.8 billion revenue passenger kilometers - 3.7 percent of total international traffic (Cederholm 2014). 


\section{Restaurant Industry}

On average, U.S. residents eat out 5.8 times each week, generating in excess of $\$ 2,600$ spent per person annually (Katje 2015). During an outbreak, consumers may alter their behavior due to the worry of contagion - individuals may fear associating with others and chose to reduce or eliminate their patronage of eating establishments. In a CNBC report, GuestMetrics, a firm that tracks the consumer and hospitality industries, states, "During the first week of October in Dallas, the number of diners at restaurants was 2 percent lower than the same period a year earlier. It fell further in the following week, down 5 percent from the prior year..." (Eisen 2014).

\section{Cruise Industry}

Cruise lines, because they mandate customers be in close proximity, suffer a similar effect as airlines and restaurants: contagious diseases elicit a withdrawal response from potential customers. In addition, cruise lines may find it necessary to alter their routes to avoid spreading disease. During the Ebola crisis, cruise lines rerouted ships that were scheduled to stop in west African ports, and authorities in Mexico denied permission to dock to a Carnival cruise ship because one of the ship's passengers may have come in contact with Ebola-contaminated specimens. The resulting impact was gauged in a Los Angeles Times article, which reported that shares of Carnival, the world's largest cruise line, dropped 12.64 percent during the height of the crisis (Martin, 2014).

\section{Pharmaceutical Industry}

The discussion of Ebola's impact thus far has highlighted the anticipated negative consequences. An upside, however, may exist, as pharmaceutical companies might reap benefits from the outbreak. To help combat the spread of Ebola, these companies have geared up research and development, and production of vaccines against and drugs, such as ZMapp and antivirals, to treat Ebola (Lorenzetti 2014). Forbes reported that Tekmira Pharmaceuticals, one company in pursuit of a vaccine, demonstrated increases in shares prices of 125 percent on the year to October 23, 2014 (Rolph 2014).

Beyond the three aforementioned influences on security prices, the timing of the Ebola crisis coincidently coincides with the beginning of the fall in crude oil prices, as well as the tethered fall in derivatives of crude. This is important factor, because at the time when the Ebola crisis is reaching its peak, the rhetoric surrounding the fall in crude prices is that consumers now have more discretionary 
income, which provides a market force in the opposite direction as the force resulting from the Ebola crisis. To ensure that the findings are not influenced by the start of this large-scale event, an additional control will be used to account for this. In the end, the aim will be to simultaneously tease-out these individual occurrences, and better understand their influence on security returns.

\section{DATA SOURCE AND SELECTION PROCEDURE}

Individual stock return data, crude oil ETF data, and Fama-French factors are all obtained through a combination of databases accessed via Wharton Research Data Services (WRDS), as well as YCharts. Put-Call Ratio and VIX-Investor Fear Gauge data are obtained through the Chicago Board of Options Exchange. The final dataset spans calendar 2014, captures 86 firms, 252 trading days, and a total of 21,331 observations.

In terms of sectors of the economy, we are most interested in stocks that were likely to be most affected by sentiment shifts. In pursuit of this, we study firms that were on the forefront of the crisis based on media commentary regarding the firm having any type of association with the Ebola crisis. Table 1 provides a breakdown of the industries that were media mainstays during the Ebola crisis. Each industry is parsed based on ex ante beliefs about the Ebola crisis having a positive or negative influence on overall industry returns.

\begin{tabular}{clr} 
& \multicolumn{2}{c}{ Table 1 } \\
Industry Breakdown & \\
\hline- & \multicolumn{1}{c}{ Industry } & Firms \\
\hline- & Airlines & 31 \\
- & Theme Parks \& Casinos & 17 \\
- & Cruise Ships & 7 \\
- & Cocoa & 3 \\
+ & Food \& Groceries & 2 \\
+ & Pharmaceuticals & 8 \\
+ & Hazmat \& Protective Gear & 7 \\
+ & Video Conferencing & 3 \\
$?$ & Hospitals \& Insurance & 4 \\
\hline & & 86
\end{tabular}

Table 1 contains a count, by industry, of the number of publicly traded firms included in the study. The total sample consists of 86 firms across the 252 trading days of 2014 that amount to a total of 21,331 unique firm/day observations. To be included in the sample, a firm had to be referenced in the media in terms of having a direct association with the Ebola outbreak. See Appendix for list of firms. 
Table 1 contains a count, by industry, of the number of publicly traded firms included in the study. The total sample consists of 86 firms across the 252 trading days of 2014 that amount to a total of 21,331 unique firm/day observations. To be included in the sample, a firm had to be referenced in the media in terms of having a direct association with the Ebola outbreak. See Appendix for list of firms.

\section{METHODOLOGY}

\section{Timeline}

In 2014 alone, the Centers for Disease Control and Prevention (CDC) reported 20,171 cases of Ebola across Guinea, Liberia, and Sierra Leone. While tragic, the objective of this research is to determine whether or not the Ebola crisis was priced in U.S. markets. In order to ascertain that, it is necessary to document Ebola news as it not only relates to Americans, but as it relates to Americans who contracted the disease (or could have contracted the disease) on U.S. soil. With this particular focus, a "U.S.-relevant" Ebola timeline boils down to eighteen dispersed days beginning on September 19, 2014 and ending on November 10, 2014. Figure 1 provides a bit of detail associated with those days. It is worth noting that although the timeline begins on September 19, 2014 with an already infected Thomas Duncan boarding a flight that is bound for Dallas, the country is unaware until September 30, 2014. On that day, September 30th, the CDC announced not only that Thomas Duncan is infected with the disease, but also that, for approximately eleven days, was free to roam the city. This sparks the beginning of the panic.

Figure 1 provides headline information, the date and day of the event, and whether the news headline is negative or positive in nature. The "non-event" column highlights information that is relevant to a later chapter of the Ebola outbreak story, but not something that was known to the public as it was occurring. Therefore, these "non-event" days will not be incorporated into the analysis. 


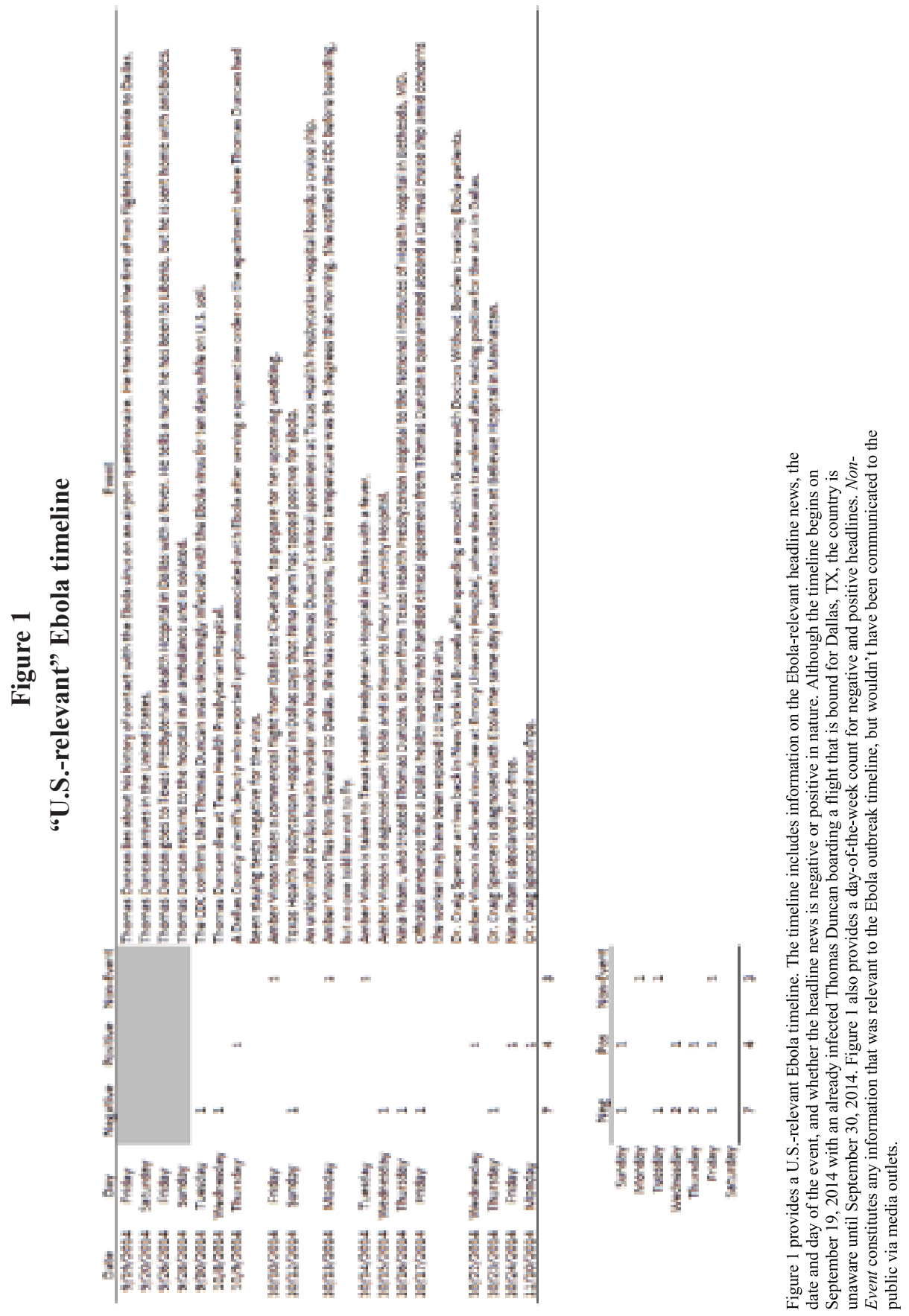


Figure 1 provides a U.S.-relevant Ebola timeline. The timeline includes information on the Ebola-relevant headline news, the date and day of the event, and whether the headline news is negative or positive in nature. Although the timeline begins on September 19, 2014 with an already infected Thomas Duncan boarding a flight that is bound for Dallas, TX, the country is unaware until September 30, 2014. Figure 1 also provides a day-of-the-week count for negative and positive headlines. Non-Event constitutes any information that was relevant to the Ebola outbreak timeline, but wouldn't have been communicated to the public via media outlets.

\section{Investor Sentiment}

The standard finance model contends for a world in which dispassionate investors force capital market prices to equal the rational present value of expected future cash flows. However, behavioral finance aims to augment the customary model with the idea that investors are subject to sentiment. Sentiment, in this context, refers to investor psychology, and opinions about future cash flows and investment risks that are not justified by the facts at hand. As the volume of studies that use investor sentiment to understand shifts in asset prices grows, so does the variety of investor sentiment proxy measures. We incorporate both the Put-Call Ratio (PCR), introduced by Dennis and Mayhew (2002), along with the VIX-Investor Fear Gauge (VIX), introduced by Whaley (2000). Both of these measures are computed daily by the Chicago Board of Options Exchange (CBOE) and are widely used by academics and practitioners as measures of investor sentiment. Often, these indicators are used as contrarian tools: when market participants are most bullish, the likelihood of a downside reversal is greatest; when investors become overly bearish, a market rally may be on the horizon. 
Figure 2

2014 Investor sentiment proxies (PCR and VIX)

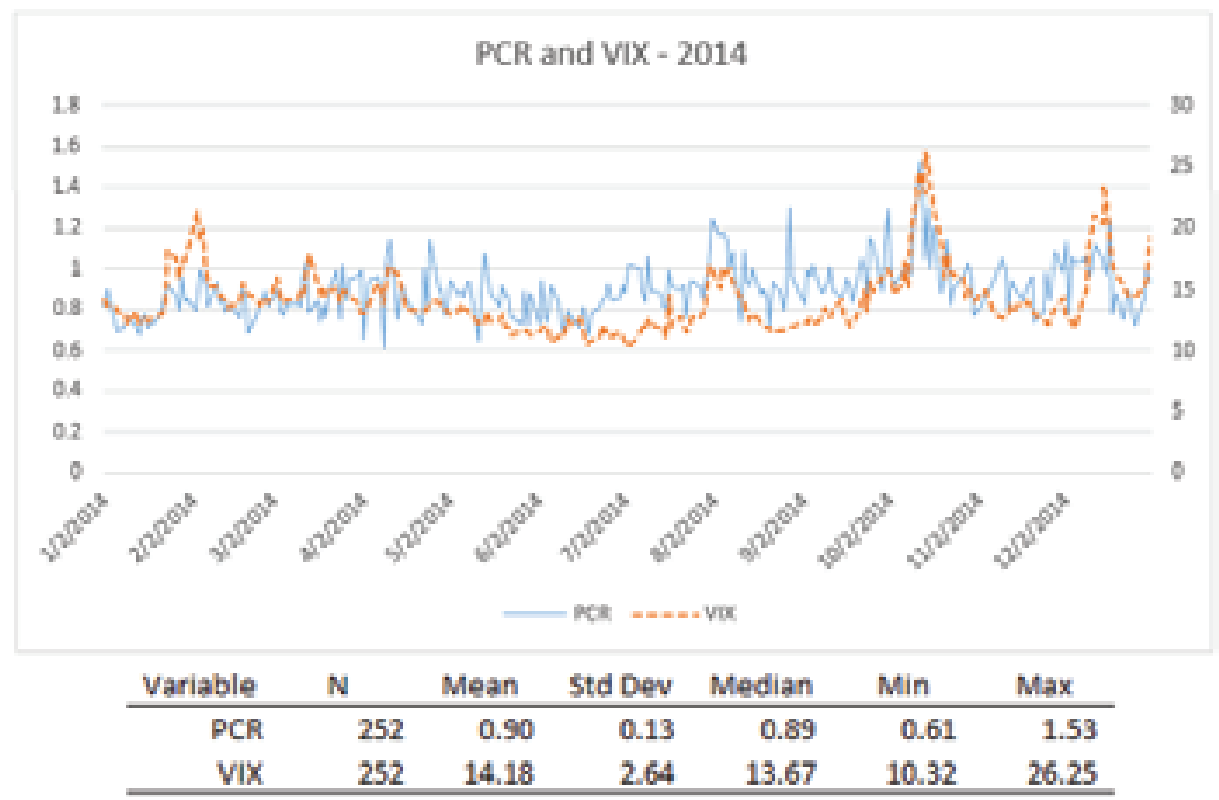

Figure 2 provides 2014 investor sentiment proxies (PCR and VIX). Using all individual securities with exchange-traded options, the PCR = Volume of put option contracts / Volume of call option contracts. VIX is the implied volatilities, calculated by using the Black-Scholes option pricing model, of options on equities on the S\&P 100 index.

The CBOE computes the PCR daily by adding together all of the call and put options that are traded on all individual equities, as well as on various indices. The finalized PCR $=$ Volume of put option contracts / Volume of call option contracts. On days when the major averages perform strongly, the number of calls bought typically far outweighs the number of puts, resulting in a relatively low put/call ratio. On days when the market is weak, the number of puts bought generally outnumbers the purchase of calls. Although a value of 1.00 might seem to be a "neutral" reading, empirically it has been observed that there are more calls than puts bought on what would be considered an "average" day. As a result, a PCR of approximately 0.80 is considered "normal". Markets are considered "strong" when the ratio falls below 0.70 and "weak" when the ratio rises above 1.10.

The VIX, on the other hand, is constructed on any trading day using the implied volatilities, calculated by using the Black-Scholes option pricing model, of options on equities on the S\&P 100 index. Figure 2 provides a plot of both the PCR and VIX, during 2014. To test if different levels of investor sentiment is priced, we parse both the PCR and VIX into terciles in order to clearly differentiate between 
high volatility (weak market) and low volatility (strong market) periods.

\subsection{Beginning of the Collapse in Crude Prices}

\section{Figure 3}

\section{Crude Prices in Relation to Ebola Outbreak}

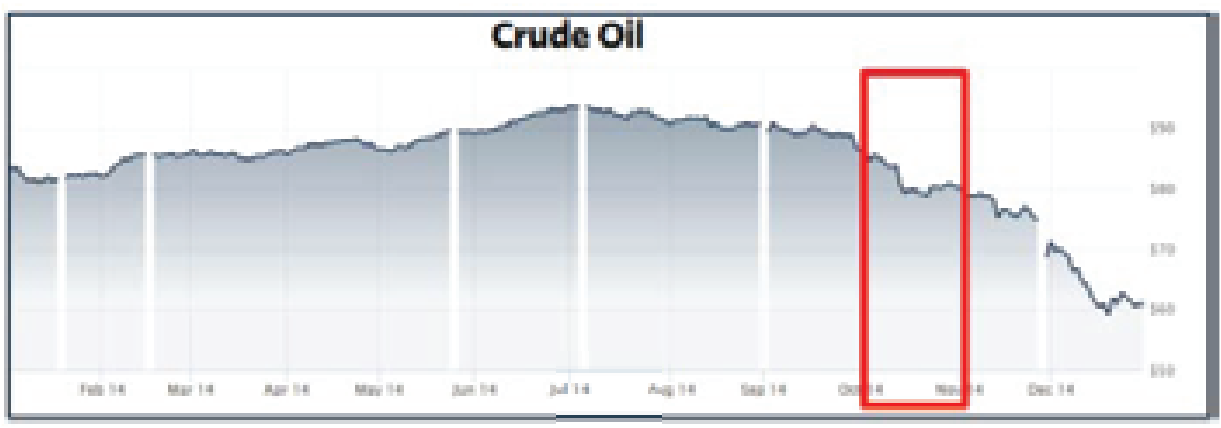

Figure 3 provides a 2014 price chart for Light Sweet Crude. The highlighted section spans the timeline of the Ebola outbreak.

The timing of the Ebola outbreak, coincidently, coincides with the beginning of the collapse in crude prices. At the time, Ebola and energy prices were two of the biggest discussion topics around. With respect to crude prices, Figure 3 shows that for the months of September through December of 2014 saw the price per barrel fall from approximately $\$ 90$ to $\$ 70$ (-22\%). The media rhetoric with respect to this fall had much to do with the consumer suddenly having more disposable income, which was at the time, thought to be a catalyst for economic stimulus. Additionally, the fall in crude prices was also thought to be a benefit to any industries that used energy as an input. The decrease in this input cost was thought to again be a cost saving catalyst. As a consequence, there were two chief competing forces. The Ebola outbreak acted as a headwind while the fall in crude prices represented a tailwind. To ensure that the results of this study are not a function of the beginning of the collapse in energy prices, an energy control variable is introduced.

\section{Model}

Based on previous research into factor models, specifically, Fama and French (1993 \& 1996), and Carhart (1997), the following regression is estimated to control for market, size, value, and momentum factors. The time subscript is suppressed. 


$$
R_{i}=\alpha+\sum_{j=1}^{4} \Omega_{j} \phi_{j}+\beta_{1} \lambda_{1}+\beta_{2} \lambda_{2}+\beta_{3} \lambda_{3}+\beta_{4} \lambda_{4}+\beta_{5} \lambda_{5}+\beta_{6} \lambda_{6}+\beta_{7} \lambda_{7}+\varepsilon_{i}
$$

$R_{i}=$ Close-to-Close return on stock $i$

$\alpha=$ the intercept term

$\Omega=$ a vector of coefficients for standard control variables (Rm-Rf, SMB, HML, UMD)

$\phi=$ the values of the control variables

$\beta_{1}$ through $\beta_{5}=$ regression coefficients for $\lambda_{1}$ through $\lambda_{5}$, respectively

$\lambda_{1}=1$ if negative Ebola crisis news day, 0 otherwise

$\lambda_{2}=1$ if lagged negative Ebola crisis news day, 0 otherwise

$\lambda_{3}=1$ if positive Ebola crisis news day, 0 otherwise

$\lambda_{4}=1$ if lagged positive Ebola crisis news day, 0 otherwise

$\lambda_{5}=$ Percent change in the value of crude oil

$\lambda_{6}=1$ in low volatility environment as per PCR (VIX), 0 otherwise

$\lambda_{7}=1$ in high volatility environment as per PCR (VIX), 0 otherwise

$\varepsilon=$ the error term

$R_{i}$ represents the return on the $i^{t h}$ firm (at time $t$ ). The four control variables are the excess return on the market portfolio $\left(R_{M}-R_{f}\right)$, the difference between the returns of value-weighted portfolios of small and big firm stocks (SMB), the difference in returns of value-weighted portfolios of high and low book-to-market stocks $(H M L)$, and the difference in returns of value-weighted portfolios of firms with high and low prior momentum (UMD), or up minus down.

\section{EMPIRICAL RESULTS}

\section{Summary Statistics}

The analysis begins with a comparison of simple summary statistics for each of the 86 firms in the study. We calculate and compare each variable on Ebola headline days versus non-Ebola headline days. The four major variable categories are return, share volume, share turnover, and trades. On the whole, mean share volume, mean dollar volume, mean share turnover, and mean number of trades are all statistically higher (at the $1 \%$ level) on Ebola headline days than otherwise. More specifically, average daily share volume goes from 2.58 million shares to 4.23 million shares and average daily number of trades goes from 10,574 to 16,548 as you move from non-news days to news days. Additionally, share turnover, measured as daily share volume/shares outstanding, increases from $1.30 \%$ to $5.21 \%$ as again you move from non-news days to news days. These metrics demonstrate a spike in market activity as a direct result of new information, regarding the Ebola outbreak, becoming available. 
Whereas pure activity metrics spiked to a statistically significant degree, individual stock return metrics did not. We observe an average daily return go from $0.11 \%$ to $0.37 \%$, however, this difference is not statistically different from zero. Excess stock return, measured as individual stock return less the return on the market, on the other hand, is statistically larger (at the 5\% level) on Ebola news days. More specifically, the average daily excess return on non-news days is $0.05 \%$, compared to $0.52 \%$ on Ebola news days.

\section{Table 2}

\section{Comparison of summary statistics (Ebola vs. Non-Ebola headline days)}

\begin{tabular}{|c|c|c|c|c|c|c|c|c|c|c|}
\hline News & Variable & $\mathrm{N}$ & Mean & Std Dev & \multicolumn{2}{|r|}{ Median } & \multicolumn{2}{|r|}{ Min } & Max & \multirow[t]{2}{*}{ t-test } \\
\hline 0 & \multirow[t]{2}{*}{ Return } & 20,228 & $0.11 \%$ & $2.48 \%$ & & $0.05 \%$ & & $-32.86 \%$ & $50.49 \%$ & \\
\hline 1 & & 846 & $0.37 \%$ & $6.38 \%$ & & $-0.16 \%$ & & $-42.86 \%$ & $83.70 \%$ & \\
\hline \multirow[t]{2}{*}{0} & \multirow{2}{*}{ Return - Market } & 20,228 & $0.05 \%$ & $2.38 \%$ & & $-0.02 \%$ & & $-33.53 \%$ & $50.74 \%$ & \multirow{2}{*}{ * } \\
\hline & & 846 & $0.52 \%$ & $6.00 \%$ & & $0.09 \%$ & & $-43.00 \%$ & $85.00 \%$ & \\
\hline 0 & \multirow{2}{*}{ Volume } & 20,229 & $2,583,430$ & $4,988,470$ & & 879,341 & & 27 & $153,766,718$ & \multirow[b]{2}{*}{$* *$} \\
\hline 1 & & 847 & $4,230,817$ & $7,208,340$ & & $1,373,798$ & & 1,109 & $60,661,438$ & \\
\hline \multirow{2}{*}{0} & \multirow[t]{2}{*}{ Dollar Volume } & 20,229 & \multirow{2}{*}{$\begin{array}{l}\$ 118,985,598 \\
\$ 173,640,972\end{array}$} & $\$ 189,858,733$ & $\$$ & $39,085,890$ & $\$$ & 193 & \multirow{2}{*}{$\begin{array}{l}\$ 3,424,384,880 \\
\$ 2,151,382,937\end{array}$} & \multirow[b]{2}{*}{$* *$} \\
\hline & & 847 & & $\$ 261,954,837$ & $\$$ & $58,926,166$ & $\$$ & 1,298 & & \\
\hline \multirow{2}{*}{$\begin{array}{l}0 \\
1\end{array}$} & \multirow[t]{2}{*}{$\Delta$ Dollar Volume } & 20,143 & $(376,269)$ & $\$ 102,318,659$ & $\$$ & $(45,283)$ & $\$$ & $(2,275,342,877)$ & $\$ 2,207,254,207$ & \multirow{2}{*}{ * } \\
\hline & & 846 & $7,773,487$ & $\$ 115,503,697$ & $\$$ & 280,068 & $\$$ & $(740,763,064)$ & $993,585,871$ & \\
\hline \multirow[t]{2}{*}{0} & \multirow[t]{2}{*}{$\% \Delta$ Dollar Volume } & 20,143 & $24.53 \%$ & $550.40 \%$ & & $-1.71 \%$ & & $-99.00 \%$ & $70709.00 \%$ & \\
\hline & & 846 & $22.89 \%$ & $142.00 \%$ & & $3.34 \%$ & & $-93.00 \%$ & $3501.00 \%$ & \\
\hline \multirow[t]{2}{*}{0} & \multirow[t]{2}{*}{ Turnover } & 20,229 & $1.30 \%$ & $3.82 \%$ & & $0.80 \%$ & & $0.00 \%$ & $181.51 \%$ & \multirow{2}{*}{$* *$} \\
\hline & & 847 & $5.21 \%$ & $37.00 \%$ & & $1.24 \%$ & & $0.00 \%$ & $894.00 \%$ & \\
\hline \multirow[t]{2}{*}{0} & \multirow{2}{*}{$\Delta$ Turnover } & 20,143 & $-0.01 \%$ & $3.07 \%$ & & $-0.01 \%$ & & $-118.00 \%$ & $123.84 \%$ & \\
\hline & & 846 & $0.11 \%$ & $32.00 \%$ & & $0.02 \%$ & & $-585.00 \%$ & $696.00 \%$ & \\
\hline \multirow[t]{2}{*}{0} & \multirow[t]{2}{*}{$\% \Delta$ Turnover } & 20,226 & $24.89 \%$ & $553.61 \%$ & & $-2.01 \%$ & & $-99.00 \%$ & $71663.00 \%$ & \\
\hline & & 847 & $20.26 \%$ & $96.00 \%$ & & $3.23 \%$ & & $-93.00 \%$ & $1860.00 \%$ & \\
\hline \multirow[t]{2}{*}{0} & Trades & 10,550 & 10,574 & 18,270 & & 4,330 & & - & 338,999 & \\
\hline & & 447 & 16,548 & 26,531 & & 6,842 & & 174 & 177,025 & $* *$ \\
\hline 0 & $\Delta$ Trades & 10,505 & (52) & 8,115 & & (28) & & $(217,800)$ & 188,162 & \\
\hline 1 & & 446 & 661 & 13,101 & & 94 & & $(112,028)$ & 135,155 & \\
\hline 0 & $\% \Delta$ Trades & 10,504 & $12.95 \%$ & $122.83 \%$ & & $-1.58 \%$ & & $-100.00 \%$ & $7200.00 \%$ & \\
\hline 1 & & 446 & $13.50 \%$ & $53.00 \%$ & & $3.19 \%$ & & $-92.00 \%$ & $418.00 \%$ & \\
\hline
\end{tabular}

Table 2 provides 2014 summary statistics, in daily frequencies, across four main stock metrics (return, volume, turnover, trades). Both raw (as collected) and transformed variables are reported. Summary statistics are calculated both on days where there was Ebola headline news, and also on days where there was not. Here, Return is the daily CRSP cum dividend percent return. Return - Market is the CRSP cum dividend percent return less the CRSP S\&P 500 index return. Turnover is $100 *$ (Volume/Shares), where Volume refers to the number of shares traded on a given day and Shares equals the outstanding shares at the end of that same day. Dollar Volume is the daily dollar volume and Trades is the daily number of trades. $\Delta$ refers to the first difference of the corresponding variable. $\% \Delta$ refers to the percentage change in the corresponding variable. The final dataset spans calendar 2014, captures 86 firms, 252 trading days, and a total of 21,331 observations. Two-sample, unpaired t-test statistics highlight statistically significant differences. ${ }^{*},{ }^{* *}$ denote statistical significance at the .05 and .01 levels, respectively.

\section{Aggregated and Contemporaneous Regressions}

This section of the study attempts to ascertain whether or not, in the aggregate, Ebola news days (either negative or positive) were priced factors. To first test this, Panel A of Table 3 presents coefficients for negative and positive Ebola news days 
separately, and in the absence of any other control variables (aside from market, size, value, and momentum). From columns two and three of Panel A we see that, in the aggregate, negative Ebola days had no impact on contemporaneous stock returns, whereas positive Ebola news days did. Thus, while the rhetoric surrounding the Ebola outbreak was that of panic selling, negative security returns were not a direct result of negative Ebola headlines. However, positive Ebola news days did in fact influence contemporaneous security returns, in a positive way.

Table 3

Ebola's Contemporaneous Influence on Aggregate Data

\begin{tabular}{|c|c|c|c|c|c|c|c|c|c|c|c|c|}
\hline \multirow{2}{*}{$\begin{array}{r}\text { Panel: } \\
\text { Intercept }\end{array}$} & \multicolumn{6}{|c|}{ A: Ebola News } & \multicolumn{4}{|c|}{ B: Control Variables } & \multicolumn{2}{|c|}{ C: Combined } \\
\hline & 0.001 & $* *$ & 0.001 & $* *$ & 0.001 & $* *$ & 0.001 & $* *$ & 0.001 & $* *$ & 0.001 & $* *$ \\
\hline & (4.47) & & $(4.20)$ & & $(4.03)$ & & (3.46) & & (3.22) & & (3.12) & \\
\hline \multirow[t]{2}{*}{$\mathrm{Rm}-\mathrm{Rf}$} & 0.750 & $* *$ & 0.749 & $* *$ & 0.766 & $* *$ & 0.803 & $* *$ & 0.750 & $* *$ & 0.805 & $* *$ \\
\hline & (26.51) & & (26.41) & & (26.65) & & (27.12) & & (25.59) & & (26.22) & \\
\hline \multirow[t]{2}{*}{ SMB } & 0.317 & $* *$ & 0.315 & $* *$ & 0.324 & $* *$ & 0.342 & $* *$ & 0.323 & $* *$ & 0.357 & $* *$ \\
\hline & (8.35) & & $(8.27)$ & & $(8.52)$ & & (8.95) & & $(8.37)$ & & (9.17) & \\
\hline \multirow[t]{2}{*}{ HML } & -0.265 & $* *$ & -0.260 & $* *$ & -0.256 & $* *$ & -0.191 & $* *$ & -0.259 & $* *$ & -0.165 & $* *$ \\
\hline & $(-4.51)$ & & $(-4.42)$ & & $(-4.35)$ & & $(-3.18)$ & & $(-4.39)$ & & $(-2.71)$ & \\
\hline \multirow[t]{2}{*}{ UMD } & 0.254 & $* *$ & 0.259 & $* *$ & 0.228 & $* *$ & 0.183 & $* *$ & 0.259 & $* *$ & 0.170 & $* *$ \\
\hline & (5.55) & & $(5.64)$ & & $(4.88)$ & & $(3.86)$ & & $(5.61)$ & & (3.51) & \\
\hline \multirow[t]{2}{*}{ Neg Ebola News } & & & 0.001 & & & & & & & & 0.002 & \\
\hline & & & $(1.22)$ & & & & & & & & (1.34) & \\
\hline \multirow[t]{2}{*}{ Pos Ebola News } & & & & & 0.005 & $* *$ & & & & & 0.004 & ** \\
\hline & & & & & $(3.08)$ & & & & & & (2.92) & \\
\hline \multirow[t]{2}{*}{$\% \Delta$ Crude } & & & & & & & -0.085 & $* *$ & & & -0.087 & $* *$ \\
\hline & & & & & & & $(-5.99)$ & & & & $(-6.04)$ & \\
\hline \multirow[t]{2}{*}{ Low Put-Call Ratio } & & & & & & & & & 0.000 & & -0.001 & \\
\hline & & & & & & & & & $(-0.85)$ & & $(-1.13)$ & \\
\hline \multirow[t]{2}{*}{ High Put-Call Ratio } & & & & & & & & & 0.000 & & -0.001 & \\
\hline & & & & & & & & & $(-0.55)$ & & $(-1.90)$ & \\
\hline Observations & 21,074 & & 21,074 & & 21,074 & & 21,074 & & 21,074 & & 21,074 & \\
\hline Adj R-Sq & $7.54 \%$ & & $7.54 \%$ & & $7.57 \%$ & & $7.69 \%$ & & $7.53 \%$ & & $7.73 \%$ & \\
\hline
\end{tabular}

Table 3 shows aggregate OLS estimates of the coefficients from equation (1). Dummy variables are created for Ebola news days. The seven negative headline days are differentiated from the four positive headline days. Put-Call Ratio is used to capture market sentiment. Put-Call Ratio is broken into terciles, with mid-levels representing the benchmark. Not presented are results using VIX terciles to capture market sentiment. Results are qualitatively similar. Crude represents the daily closing futures price for light sweet crude oil. $\Delta$ refers to the first difference of the corresponding variable. $\% \Delta$ refers to the percentage change in the corresponding variable. The final dataset spans calendar 2014, captures 86 firms, 252 trading days, and a total of 21,331 observations. t-statistics are in parenthesis. *, ** denote statistical significance at the .05 and .01 levels, respectively.

Moving beyond the isolated Ebola dummy variables, an energy control is introduced to correct for any possible activity that was a direct result of the fall in crude prices. Additionally, a terciled put-call ratio is also introduced in an attempt to capture the overall sentiment of the market. Panel B shows the individual influence of each of these control variables. From here we see a negative and statistically 
significant coefficient for crude oil prices. This means that as energy prices fell, the market interpreted that as good economic news, and security prices rose as a result. Unlike crude prices, however, the coefficients for market sentiment were insignificant, meaning that the mood of the market was not a priced factor. Thus, in terms of aggregate security returns, crude prices were influential, but market sentiment was not. Finally, Panel $\mathrm{C}$ of Table 3 combines all controls, and also tests for negative and positive Ebola news events within the same OLS regression. Consistent with their individual and separate results from Panel A, negative news days were not priced, whereas positive news days were.

\section{Aggregated and Lagged Regressions}

This next segment of the study takes one incremental step beyond section 5.2. Instead of just regressing security returns on Ebola news days, we now regress security returns on Ebola news days as well as lagged Ebola news days. The objective is to learn whether or not the market reacts to headline events, and whether that reaction is stable or transitory in nature. Table 4 is broken up into three panels. Panel A provides OLS coefficients on aggregate data, for both negative news days and lagged negative news days, Panel B does the same for positive news days, and Panel $\mathrm{C}$ combines all variables into one regression.

Panel $\mathrm{C}$ of Table 4 shows that, on the aggregate, neither negative nor positive Ebola news events are priced. However, the negative lagged Ebola coefficient is positive and statistically significant. This curious result indicates that the market does not price negative or positive Ebola headlines into security prices, but that security prices do react positively, one trading day after a negative event occurs. This result is loosely consistent with Tetlock (2007) who shows that high levels of media pessimism predict downward pressure on market prices, followed by a revision to fundamentals. 
Table 4

Ebola's Lagged Influence on Aggregate Data

\begin{tabular}{|c|c|c|c|c|c|c|}
\hline Panel: & A: Negative & & B: Positive & & C: Combined & \\
\hline \multirow[t]{2}{*}{ Intercept } & 0.001 & $*$ & 0.001 & $* *$ & 0.001 & $* *$ \\
\hline & $(2.93)$ & & (3.10) & & $(2.88)$ & \\
\hline \multirow[t]{2}{*}{$\mathrm{Rm}-\mathrm{Rf}$} & 0.795 & $* *$ & 0.809 & $* *$ & 0.801 & $* *$ \\
\hline & (26.11) & & (26.48) & & $(26.05)$ & \\
\hline \multirow[t]{2}{*}{ SMB } & 0.354 & $* *$ & 0.359 & $* *$ & 0.356 & $* *$ \\
\hline & (9.10) & & (9.22) & & (9.15) & \\
\hline \multirow[t]{2}{*}{$\mathrm{HML}$} & -0.176 & $* *$ & -0.176 & $* *$ & -0.176 & $* *$ \\
\hline & $(-2.90)$ & & $(-2.89)$ & & $(-2.88)$ & \\
\hline \multirow[t]{2}{*}{ UMD } & 0.183 & $* *$ & 0.162 & $* *$ & 0.171 & $* *$ \\
\hline & (3.84) & & (3.37) & & $(3.54)$ & \\
\hline \multirow[t]{2}{*}{ Neg Ebola News } & 0.000 & & & & 0.001 & \\
\hline & $(0.18)$ & & & & $(0.55)$ & \\
\hline \multirow[t]{2}{*}{ Lag Neg Ebola News } & 0.005 & $* *$ & & & 0.004 & $* *$ \\
\hline & (4.17) & & & & (3.23) & \\
\hline \multirow[t]{2}{*}{ Pos Ebola News } & & & 0.004 & $* *$ & 0.002 & \\
\hline & & & $(2.86)$ & & (1.49) & \\
\hline \multirow[t]{2}{*}{ Lag Pos Ebola News } & & & -0.002 & & -0.002 & \\
\hline & & & $(-1.25)$ & & $(-1.23)$ & \\
\hline \multirow[t]{2}{*}{$\% \Delta$ Crude } & -0.086 & $* *$ & -0.086 & $* *$ & -0.084 & $* *$ \\
\hline & $(-5.94)$ & & $(-5.94)$ & & $(-5.80)$ & \\
\hline \multirow[t]{2}{*}{ Low Put-Call Ratio } & 0.000 & & 0.000 & & 0.000 & \\
\hline & $(-0.94)$ & & $(-1.04)$ & & $(-0.87)$ & \\
\hline \multirow[t]{2}{*}{ High Put-Call Ratio } & -0.001 & & -0.001 & & -0.001 & \\
\hline & $(-1.86)$ & & $(-1.49)$ & & $(-1.80)$ & \\
\hline Observations & 21,073 & & 21,073 & & 21,073 & \\
\hline Adj R-Sq & $7.77 \%$ & & $7.73 \%$ & & $7.77 \%$ & \\
\hline
\end{tabular}

Table 4 shows aggregate OLS estimates of the coefficients from equation (1). Dummy variables are created for Ebola news days and for lagged news days. The seven negative headline days are differentiated from the four positive headline days. Put-Call Ratio is used to capture market sentiment. Put-Call Ratio is broken into terciles, with mid-levels representing the benchmark. Not presented are results using VIX terciles to capture market sentiment. Results are qualitatively similar. Crude represents the daily closing futures price for light sweet crude oil. $\Delta$ refers to the first difference of the corresponding variable. $\% \Delta$ refers to the percentage change in the corresponding variable. The final dataset spans calendar 2014, captures 86 firms, 252 trading days, and a total of 21,331 observations. t-statistics are in parenthesis. *, ** denote statistical significance at the .05 and .01 levels, respectively.

\section{Disaggregated and Lagged Regressions}

As a final step in the analysis, we disaggregate the data and present separate results for the four largest industries represented (airlines, cruise ships, 
pharmaceuticals, and restaurants). The objective is to establish whether or not the Ebola outbreak had a non-uniform impact across different industries. Table 5 presents OLS coefficients on industry-specific data, for both negative and positive news days, and in both on a contemporaneous and lagged manner.

\section{Table 5}

\section{Ebola's Lagged Influence on Industry-Specific Data}

\begin{tabular}{|c|c|c|c|c|c|c|c|c|}
\hline Panel: & A: Airline & & B: Cruise Ship & & C: Pharma & & D: Restaurant & \\
\hline \multirow[t]{2}{*}{ Intercept } & 0.001 & $*$ & 0.001 & & 0.001 & & 0.001 & $* *$ \\
\hline & $(2.12)$ & & (1.12) & & $(0.33)$ & & $(2.94)$ & \\
\hline \multirow[t]{2}{*}{$\mathrm{Rm}-\mathrm{Rf}$} & 1.093 & $* *$ & 1.410 & $* *$ & 0.148 & & 0.742 & $* *$ \\
\hline & $(20.40)$ & & $(16.96)$ & & $(0.61)$ & & $(18.88)$ & \\
\hline \multirow[t]{2}{*}{ SMB } & 0.293 & $* *$ & -0.109 & & 1.492 & $* *$ & 0.549 & $* *$ \\
\hline & $(4.32)$ & & $(-1.03)$ & & $(4.90)$ & & $(11.02)$ & \\
\hline \multirow[t]{2}{*}{ HML } & -0.006 & & -0.039 & & -1.979 & $* *$ & -0.045 & \\
\hline & $(-0.05)$ & & $(-0.24)$ & & $(-4.16)$ & & $(-0.58)$ & \\
\hline \multirow[t]{2}{*}{ UMD } & 0.368 & $* *$ & -0.053 & & 0.817 & $*$ & 0.098 & \\
\hline & $(4.36)$ & & $(-0.40)$ & & $(2.16)$ & & $(1.58)$ & \\
\hline \multirow[t]{2}{*}{ Neg Ebola News } & -0.009 & $* *$ & -0.014 & $* *$ & 0.050 & $* *$ & -0.005 & ** \\
\hline & $(-4.42)$ & & $(-4.33)$ & & $(5.26)$ & & $(-3.62)$ & \\
\hline \multirow[t]{2}{*}{ Lag Neg Ebola News } & 0.011 & $* *$ & 0.007 & $*$ & -0.009 & & 0.007 & ** \\
\hline & $(4.93)$ & & $(2.05)$ & & $(-0.90)$ & & $(4.21)$ & \\
\hline \multirow[t]{2}{*}{ Pos Ebola News } & -0.004 & & -0.005 & & 0.012 & & 0.004 & $*$ \\
\hline & $(-1.41)$ & & $(-1.17)$ & & $(0.97)$ & & $(2.09)$ & \\
\hline \multirow[t]{2}{*}{ Lag Pos Ebola News } & 0.003 & & 0.000 & & -0.016 & & -0.002 & \\
\hline & $(1.22)$ & & $(0.01)$ & & $(-1.39)$ & & $(-1.03)$ & \\
\hline \multirow[t]{2}{*}{$\% \Delta$ Crude } & -0.281 & $* *$ & -0.172 & $* *$ & 0.243 & $*$ & -0.076 & $* *$ \\
\hline & $(-11.18)$ & & $(-4.40)$ & & $(2.14)$ & & $(-4.12)$ & \\
\hline \multirow[t]{2}{*}{ Low Put-Call Ratio } & 0.000 & & -0.003 & $*$ & 0.007 & & -0.002 & $* *$ \\
\hline & $(-0.39)$ & & $(-2.10)$ & & $(1.88)$ & & $(-3.25)$ & \\
\hline \multirow[t]{2}{*}{ High Put-Call Ratio } & -0.001 & & 0.002 & & 0.000 & & -0.001 & $*$ \\
\hline & $(-1.33)$ & & $(1.34)$ & & $(-0.05)$ & & $(-2.07)$ & \\
\hline Observations & 4,063 & & 756 & & 1,764 & & 7,435 & \\
\hline Adj R-Sq & $20.89 \%$ & & $35.29 \%$ & & $8.73 \%$ & & $11.72 \%$ & \\
\hline
\end{tabular}

Table 5 shows industry specific OLS estimates of the coefficients from equation (1). Dummy variables are created for Ebola news days and for lagged news days. The seven negative headline days are differentiated from the four positive headline days. Put-Call Ratio is used to capture market sentiment. Put-Call Ratio is broken into terciles, with mid-levels representing the benchmark. Not presented are results using VIX terciles to capture market sentiment. Results are qualitatively similar. Crude represents the daily closing futures price for light sweet crude oil. $\Delta$ refers to the first difference of the corresponding variable. $\%$ $\Delta$ refers to the percentage change in the corresponding variable. The final dataset spans calendar 2014, captures 86 firms, 252 trading days, and a total of 21,331 observations. t-statistics are in parenthesis. ${ }^{*}, *$ denote statistical significance at the .05 and .01 levels, respectively. 
One of the more interesting results comes from Panels A, B, and D. There we see that a negative Ebola news day has a statistically significant negative impact on contemporaneous returns for airline, cruise ship, and restaurant stocks. However, we then see, in the case of both airline and restaurant stocks, an even larger statistically significant return reversal the following day (cruise ship stocks experience a significant return reversal that is roughly half the amount of the previous day's fall). This return performance is consistent with the behavioral, short-term return reversal literature. For example, Subrahmanyam (2005), suggests that short-term reversal profits are evidence that market prices may reflect investor overreaction to information, or fads, or simply cognitive error. Da, Qianqiu, and Shaumburg (2014) provide additional insight by documenting that stock returns that are unexplained by earnings and cash flow fundamentals are more likely to reverse in the short run than those that are linked to fundamentals.

Two additional noteworthy results come from Panels C and D. In Panel C, we observe that the pharmaceutical industry was an industry that experienced a statistically significant positive return on negative Ebola news days. This result isn't surprising, considering the pharmaceutical stocks that were mentioned in the media were those who were working on a cure for the disease. Lastly, in Panel D we observe that the restaurant industry experienced a statistically significant positive return on positive Ebola news days. This is consistent with the market interpreting good news as a signal that public consumption would again return to normalized levels.

\section{CONCLUDING REMARKS}

In the fall of 2014, the Ebola outbreak affected normal everyday behavior for many Americans, and caused a great deal of havoc on the financial markets. We study the impact of Ebola news days (both negative and positive) on stock markets by examining daily price data for Ebola-relevant stocks that were highlighted by the media. We consider the impact and persistence of the Ebola scare on an aggregated portfolio, as well as its impact on industry-specific portfolios. We find that in the aggregate, negative Ebola news days have no impact on security returns, but when we analyze disaggregated portfolios, several industries are significantly impacted by both positive and negative Ebola news days. When studying the disaggregated portfolios, we also find a tendency for price movement to reverse itself one day after the Ebola news event, a result that is consistent with behavioral overreaction and cognitive error literature. 


\section{ACKNOWLEDGEMENT}

We gratefully accept the inaugural WRDS-SSRN Innovation Award for this particular piece of research, honoring emerging business schools. We would like to thank the participants at the 2016 Academy of Economics and Finance annual conference (Pensacola Beach, FL) for their helpful comments and insight. Additionally, we would like to thank the Department of General Business and Finance at Sam Houston State University for the funding associated with the YCharts database. Finally, we would like to thank Jose Ivan Alvarado for his excellent research assistance. This work is supported by the Sam Houston State University COBA Summer Research Grant Program.

\section{REFERENCES}

Baker, M., \& Wurgler, J. (2006). Investor sentiment and the cross-section of stock returns. The Journal of Finance, 61(4), 1645-1680.

Bollen, J., \& Mao, H. (2011). Twitter mood as a stock market predictor. Computer, 44(10), 0091-94.

Carhart, M. M. (1997). On persistence in mutual fund performance. The Journal of Finance, 52(1), 57-82.

Casey, M.J. (2014, October 15). For Ebola's Market Impact, Follow the Fear, not the Virus. Retrieved from http://blogs.wsj.com/moneybeat/2014/10/15/for-ebolasmarket-impact-follow-the-fear-not-the-virus/.

Cederholm, T. (2014). Why Ebola impacted the airline industry. Retrieved from http://marketrealist.com/2014/10/why-the-2014-ebola-outbreak-is-worse-thanprevious-outbreaks/.

Chen, M. H., Jang, S. S., \& Kim, W. G. (2007). The impact of the SARS outbreak on Taiwanese hotel stock performance: an event-study approach. International Journal of Hospitality Management, 26(1), 200-212.

Da, Z., Liu, Q., \& Schaumburg, E. (2013). A closer look at the short-term return reversal. Management Science, 60(3), 658-674.

Dennis, P. \& Mayhew, S. (2002). Risk-neutral skewness: Evidence from stock options. Journal of Financial and Quantitative Analysis, 37(3), 35-58.

Eisen, S. (2014). Consumers hunkered down during Dallas Ebola scare. Retrieved from http://www.cnbc.com/2014/10/27/dallas-ebola-scare-made-consumershunkered-down-report-says.html.

Fama, E. F., \& French, K. R. (1993). Common risk factors in the returns on stocks and bonds. Journal of Financial Economics, 33(1), 3-56. 
Fama, E. F., \& French, K. R. (1996). Multifactor explanations of asset pricing anomalies. The Journal of Finance, 51(1), 55-84.

Fang, L., \& Peress, J. (2009). Media coverage and the cross-section of stock returns. The Journal of Finance, 64(5), 2023-2052.

Katje, C. (2015). The Top 5 Restaurant ETFs for 2016. Retrieved from http://www. investopedia.com/articles/investing/120815/top-5-restaurant-etfs-2016.asp.

Lorenzetti, L. (2014). As Ebola spreads, drug companies rate to develop treatments. Retrieved from http://fortune.com/2014/10/02/as-ebola-spreads-drugcompanies-race-to-develop-treatments/.

Martin, H. (2014). With Ebola scare, travel industry hits rough patch. Retrieved from http://www.latimes.com/business/la-fi-cruise-ebola-20141018-story.html.

McTier, B. C., Tse, Y., \& Wald, J. K. (2013). Do Stock Markets Catch the Flu?. Journal of Financial and Quantitative Analysis, 48(03), 979-1000.

Rolph, D. (2014). Ebola \&amp; The Stock Market: Repercussions of Panic. Retrieved from http://www.forbes.com/sites/duncanrolph/2014/10/28/ebolathe-stock-market-repercussions-of-panic/\#41b60fc43a80.

Schmeling, M. (2009). Investor sentiment and stock returns: Some international evidence. Journal of Empirical Finance, 16(3), 394-408.

Subrahmanyam, A. (2005). Distinguishing between rationales for short-horizon predictability of stock returns. Financial Review, 40(1), 11-35.

Tetlock, P. C. (2007). Giving content to investor sentiment: The role of media in the stock market. The Journal of Finance, 62(3), 1139-1168.

Wang, Y. H., Yang, F. J., \& Chen, L. J. (2013). An investor's perspective on infectious diseases and their influence on market behavior. Journal of Business Economics and Management, 14(sup1), S112-S127.

Whaley, R. E. (2000). The investor fear gauge. Journal of Portfolio Management, 26(3).

\section{BRIEF BIOGRAPHICAL SKETCH OF AUTHORS}

Dr. Mary Funck is an associate professor of Finance. She joined SHSU's Department of General Business and Finance in 2012. Dr. Funck is originally from Iowa, and while living there earned a Bachelor and Master degree in Computer Science, and a MBA from Western Illinois University. She then earned a PhD in Finance from the University of Mississippi in 2012. She currently teaches courses in corporate finance, financial modeling, financial statement analysis, and risk management in financial institutions. Her research interest focus on financial 
education and pedagogy, capital budgeting, and the securities markets. Dr. Funck is active on campus with Beta Gamma Sigma, the COBA tailgating committee, and the First Year Experience common reader program.

Dr. Gutierrez earned his Ph.D., M.S., and B.B.A. in Finance, all from The University of Texas at San Antonio in 2010, 2002, and 2001, respectively. Dr. Gutierrez maintains a research agenda in corporate finance, market microstructure, liquidity, price dynamics, and international financial markets. His research has appeared in the Review of Quantitative Finance and Accounting, and the International Review of Economics and Finance.

\section{Appendix - Complete List of Firms Used in Study}

\begin{tabular}{|c|c|c|c|}
\hline Company Name & Industry & Company Name & Industry \\
\hline SKYWEST INC & Airline & BIOCRYST PHARMACEUTICALS INC & Pharmaceutical \\
\hline SPIRIT AIRLINES INC & Airline & SAREPTA THERAPEUTICS INC & Pharmaceutical \\
\hline VIRGIN AMERICA INC & Airline & BRAVO BRIO RESTAURANT GROUP INC & Restaurant \\
\hline AMERICAN AIRLINES GROUP INC & Airline & DUNKIN BRANDS GROUP INC & Restaurant \\
\hline ALASKA AIRGROUP INC & Airline & BLOOMIN BRANDS INC & Restaurant \\
\hline SOUTHWEST AIRLINES CO & Airline & NOODLES \& CO & Restaurant \\
\hline HAWAIIAN HOLDINGS INC & Airline & POTBELLY CORP & Restaurant \\
\hline CHINA EASTERN AIRLINES CORP LTD & Airline & EL POLLO LOCO HOLDINGS INC & Restaurant \\
\hline RYANAIR HOLDINGS PLC & Airline & DAVE \& BUSTERS ENTERTAINMENT INC & Restaurant \\
\hline CHINA SOUTHERN AIRLINES CO LTD & Airline & WENDYS CO & Restaurant \\
\hline LATAM AIRLINES GROUP S A & Airline & CRACKER BARREL OLD COUNTRY & Restaurant \\
\hline JETBLUE AIRWAYS CORP & Airline & MCDONALDS CORP & Restaurant \\
\hline REPUBLIC AIRWAYS HOLDINGS INC & Airline & RUBY TUESDAY INC & Restaurant \\
\hline COPA HOLDINGS SA & Airline & LUBYS INC & Restaurant \\
\hline UNITED CONTINENTAL HOLDINGS INC & Airline & SONIC CORP & Restaurant \\
\hline ALLEGIANT TRAVEL CO & Airline & PANERA BREAD CO & Restaurant \\
\hline DELTA AIR LINES INC & Airline & JACK IN THE BOX INC & Restaurant \\
\hline HERSHEY CO & Cocoa & STARBUCKS CORP & Restaurant \\
\hline MONDELEZ INTERNATIONAL INC & Cocoa & CHEESECAKE FACTORY INC & Restaurant \\
\hline NORWEGIAN CRUISE LINE HLDGS LTD & CruiseShip & NATHANS FAMOUS INC NEW & Restaurant \\
\hline CARNIVAL CORP & CruiseShip & PAPA JOHNS INTL INC & Restaurant \\
\hline ROYAL CARIBBEAN CRUISES LTD & CruiseShip & DARDEN RESTAURANTS INC & Restaurant \\
\hline KROGER COMPANY & Food & EINSTEIN NOAH RESTAURANT GRP INC & Restaurant \\
\hline GENERAL MILLS INC & Food & BJS RESTAURANTS INC & Restaurant \\
\hline CAMPBELL SOUP CO & Food & YUM BRANDS INC & Restaurant \\
\hline TARGET CORP & Food & DENNYS CORP & Restaurant \\
\hline WAL MART STORES INC & Food & RED ROBIN GOURMET BURGERS INC & Restaurant \\
\hline CONAGRA INC & Food & BUFFALO WILD WINGS INC & Restaurant \\
\hline TYSON FOODS INC & Food & DOMINOS PIZZA INC & Restaurant \\
\hline COSTCO WHOLESALE CORP NEW & Food & TEXAS ROADHOUSE INC & Restaurant \\
\hline HONEYWELL INTERNATIONAL INC & HazmatGear & KONA GRILL INC & Restaurant \\
\hline LAKELAND INDUSTRIES INC & HazmatGear & RUTHS HOSPITALITY GROUP INC & Restaurant \\
\hline DU PONT E I DE NEMOURS \& CO & HazmatGear & CHIPOTLE MEXICAN GRILL INC & Restaurant \\
\hline KIMBERLY CLARK CORP & HazmatGear & M G M RESORTS INTERNATIONAL & ThemeParkCasino \\
\hline H C A HOLDINGS INC & HospitalInsurance & CAESARS ENTERTAINMENT CORP & ThemeParkCasino \\
\hline TENET HEALTHCARE CORP & HospitalInsurance & SEAWORLD ENTERTAINMENT INC & ThemeParkCasino \\
\hline UNIVERSAL HEALTH SERVICES INC & HospitalInsurance & NEVADA GOLD \& CASINOS INC & ThemeParkCasino \\
\hline COMMUNITY HEALTH SYS INC NEW & HospitalInsurance & CEDAR FAIR L P & ThemeParkCasino \\
\hline TEKMIRA PHARMACEUTICALS CORP & Pharmaceutical & LAS VEGAS SANDS CORP & ThemeParkCasino \\
\hline IBIO INC & Pharmaceutical & SIX FLAGS ENTERTAINMENT CORP & ThemeParkCasino \\
\hline NEWLINK GENETICS CORP & Pharmaceutical & CISCO SYSTEMS INC & VideoConferencing \\
\hline CHIMERIX INC & Pharmaceutical & CITRIX SYSTEMS INC & VideoConferencing \\
\hline JOHNSON \& JOHNSON & Pharmaceutical & POLYCOM INC & VideoConferencing \\
\hline
\end{tabular}




\section{HIGHLIGHTS}

- In the aggregate, negative Ebola news days have no impact on security returns.

- In the disaggregate, however, several industries are significantly impacted by both negative and positive Ebola news days.

- During the height of the Ebola crisis (between September 2 and October 13, 2014), the average share price for six major U.S. airlines declined by 20.74 percent.

- In the disaggregate, there is a tendency for price movement to reverse itself one day after the Ebola news event. 